\title{
How does neuroscience explain the Bruce Reimer case?
}

\section{Como a neurociência explica o caso Bruce Reimer?}

DOI: $10.46919 / \operatorname{archv2n1-004~}$

Recebimento dos originais: 30/10/2020

Aceitação para publicação: 23/12/2020

\section{Fabiano de Abreu Rodrigues}

Master and $\mathrm{PhD}$ in Health Psychology from Université Libre des Sciences de l'Homme de Paris Master and PHD in Health Sciences with emphasis on Psychology and Neuroscience from Emil Brunner World University

Master in Freudian and Lacanian psychoanalysis from Gaio Institute Specialization in Electrical Properties of Neurons in Harvard Specialization in Clinical Nutrition by TranningHouse

Neuroscientist, Neuropsychologist, Psychologist, Psychoanalyst, Journalist and Philosopher Member of SPN - Sociedade Portuguesa de Neurociências - 814, of SBNEC - Sociedade Brasileira de Neurociências e Comportamento - 6028488, and of FENS - Federation of European Neuroscience Societies - PT30079.

Address: Costinha Street, Bairros, Castelo de Paiva, Aveiro, Portugal E-mail: deabreu.fabiano@gmail.com

\begin{abstract}
The article reports the psychology with basis in neurosciences in the Bruce Reimer case, a Canadian boy raised as a girl after losing his penis on an accident during a circumcision procedure in the 1960s. Bruce committed suicide in 2004 under the name of David. His male personality clashed with his new identity as Brenda. In this article we will go deeper into the history of the case and the probabilities for the result to be suicide.
\end{abstract}

\section{RESUMO}

$\mathrm{O}$ artigo relata a psicologia com base na neurociência no caso de Bruce Reimer, um menino canadense criado como menina após perder o pênis em um acidente durante um procedimento de circuncisão nos anos 1960. Bruce suicidou-se em 2004 com o nome de David. Sua personalidade masculina entrou em conflito com a sua nova identidade como Brenda. Neste artigo vamos nos aprofundar na história do caso e nas probabilidades para que o resultado fosse o suicídio.

\section{INTRODUCTION}

On light of neuroscience, the case of Bruce Reimer proves that organic sex and sex identity have determinants within the physical body and also psychological identity, such as sex and gender, that are different things.

In this case the Canadian baby in 1967 was an "accident". Bruce Reimer was actually inside the right body. He was a newborn boy of 8 months without any psychological distortion, but it was after having his penis carbonized that his parents became "disoriented" about how to deal with the situation, and in this 
context the parents had the unfortunate coincidence of meeting the psychologist John Money, an unethical "professional" who wanted to prove his theory. This was all the enough combination to determine the tragedy that culminated in Reimer's suicide.

Guimarães and Barboza (2014), on the study "Sexual designation in intersex children: a brief analysis of cases of ambiguous genitalia" highlights that:

At Johns Hopkins University, psychologist John Money gradually became one of the leading scholars of the time on the topic of defining sexual and gender roles. He is the author of a model that suggested, in humans, the plasticity of gender when observing certain rules. In other words, Money believed that, in terms of development and fixation of a given gender identity, biology would have repealed its laws when it was offered an environment in which the surgically designated gender was not contradicted. Money, who was gradually testing his hypotheses, formulated a model of approach for children who, due congenital or genital trauma reasons, had deformities in their genitalia. (GUIMARÃES; BARBOZA, 2014, p. 02)

We are not just genes, we are not just environments, we are a kaleidoscope of subjectivity, values, customs, culture, genetic heritage, chance, relational exchanges... in short... we are more than we can explain.

There is no dichotomy between mind and body, not even a fractional equation with exactness about genetics and the environment.

But Money tried to change all of that, as Guimarães and Barboza (2014) highlighted:

As part of the various medical-surgical interventions he proposed, Bruce should undergo "sex change" surgery, in order to "fix" his new gender. According to Diamond \& Sigmundson 12, the absolute "secret" regarding the proposed and performed procedures in Bruce would be fundamental to the success of his treatment. According to the strategy designed by Money, Bruce's family - now registered as Brenda Reimer - should also move to another city, a place where no one would know the truth. In order to prove his theory that with the prescribed treatment, Brenda's gender had been adjusted, Money relied on the existence of Brian, Bruce's twin brother, who had not been circumcised. Raised as a boy, Bruce was the ideal control case for his experiment. (GUIMARÃES; BARBOZA, 2014, p. 02)

One question remains: can Bruce's parents be held responsible for the chaos that has taken over Bruce's head?

Gutierrez Laboy (2012) highlights how traumatic it was for Bruce to know all of his history.

His brother Brian claimed that the only difference between him and me was that he had a longer hair. When she reached puberty, Money recommended that they make a vagina for her, Bruce objected doing it. Finally, her father told her the whole story. Bruce considered murdering those who atrophied him, but what he really did was try to commit suicide three times, eventually falling into a coma. After "overcoming" his "state of shock" with his father's confession, he cut his hair, dressed as a man and changed his name to David and began to live a "normal" life. After the writer John Colapinto published "How nature did it: the boy who was raised as a girl", David dedicated himself to speaking out against what had been done to him. Meanwhile, he underwent four reconstructive surgeries to physically return to being a boy and married a woman who had three children from a previous marriage. (GUTIERREZ LABOY, 2012, s.p.) 
Bruce's parents may have a portion of responsibility for his death, but I believe they were as much victims as Bruce himself. Victims of a Jewish culture of circumcision, and the prejudice of the time.

To Fausto-Sterling, the spectrum of homosexuality runs through the whole discussion around the issue of intersexuality. The biologist draws attention to the fact that Money and her collaborators developed "the" therapeutic model for intersexuality in the mid of 50s, a time when homosexuality was defined as a psychopathology. (GUIMARÃES; BARBOZA, 2014, p. 02)

And it is evident that the professionals involved in this process and especially the psychologist John Money who wanted to prove his theory found on Bruce the perfect guinea pig.

Gutierrez Laboy (2012) in his scientific article "A philosophical look at research ethics"

\begin{abstract}
But what matters here are the values that gravitated or not in Dr. Money's mind. He defended the success of his "experiment" until his death. However, as I have already indicated, David's reaction does not match his evaluation. By the way, on several occasions David claimed that he and his brother were sexually abused by Dr. Money. An important study on the outcome of what is also known as the "John / Joan" case was carried out by Diamond and Sigmundson. In this study, the validity of the used methodology is questioned and the "experiment" is classified as a failure. The curious thing is the prestige that this researcher maintained and still maintains. In an article on his memory, it is reported that Professor Money was the first honorary member of the Spanish Association of Societies of Sexology (AEES) and it was proposed that the research prize of the Spanish Federation of Societies of Sexology (FESS) bear his name27. I think the proposal was not accepted. In addition, it should be noted that Money was awarded with the Magnus Hirschfeld Medal (2002) by the German Society for Social Scientific Research on Sexuality. (GUTIERREZ LABOY, 2012, s.p.)
\end{abstract}

What is certain is that after a penis reconstruction surgery, Bruce returned to having the male identity that was stolen from him, married and had a family, however, he ended up taking his own life. This could have been avoided.

I believe that this could have been avoided, even after all the drastic trajectory of the case.

A suicidal gives evidence of its planning, in addition, generally, this behavior is the result of the depressive disorder. Bruce probably suffered from major depression. And he no longer saw any motive or motivation for living.

Today there are care programs for people with depression, as well as professionals trained in the management of patients who are sick to the point of attempting against their own lives.

And what can the Bruce Reimer case teach to neuropsychology professionals?

It teaches us that in human life, nothing is easy or simple. It also teaches that we are a complete organism, a mind that lives inside a physical brain, which coordinates a physical and psychological body.

Gutierrez Laboy (2012) corroborates with this idea:

I, at least, am convinced that nature (I understand the brain) dominates, although it is not decisive. When the Spanish golden age poet and playwright Pedro Calderón de la Barca raised the problem of destiny - of great philosophical and theological interest - he concluded that it inclines but does not force. The same could be argued about this subject: nature inclines, but does not force. The 
validity of this approach is left to others, since philosophy students question and problematize arguments instead of solving obstacles. (GUTIERREZ LABOY, 2012)

It is evident that the integrality of the being facing the long journey of life requires the maintenance of homeostasis for the preservation of mental health. And more, without mental health there will be no health at all.

The mind sets the brain in motion and it goes through the behavior. Give time and voice to this being, who needs to understand himself in order to be, and in fact become Human.

Always evolving, harmonizing desires, limitations, competences, demands and contingency of life.

Human vicissitude crosses the entire life cycle to finitude. To analyze, to look at yourself and improve to live more and better. This is the greatest human challenge. 


\section{REFERENCES}

GUIMARÃES, Anibal; BARBOZA, Heloísa Helena. DESIGNAÇÃO SEXUAL EM CRIANÇAS INTERSEXO: uma breve análise dos casos de "genitália ambígua". Available in: https://www.scielo.br/pdf/csp/v30n10/0102-311X-csp-30-10-2177.pdf. Accessed in: October 15th, 2020

GUTIERREZ LABOY, Roberto. UNA MIRADA FILOSÓFICA A LA ÉTICA DE LA INVESTIGACIÓN. Rev. Bioét., Brasília , v. 21, n. 1, p. 43-52, abr. 2013. Available in: $<$ http://www.scielo.br/scielo.php?script=sci_arttext\&pid=S1983-

80422013000100005\&lng=es\&nrm=iso>. Accessed in: October 15th, 2020. https://doi.org/10.1590/S1983-80422013000100005 